\title{
Realizing urban food policy: a discursive institutionalist analysis of Ede municipality
}

\author{
Lara V. Sibbing ${ }^{1}$ (D) Jeroen J. L. Candel ${ }^{1}$ (B) \\ Received: 3 April 2020 / Accepted: 22 November 2020 / Published online: 9 December 2020 \\ (C) The Author(s) 2020
}

\begin{abstract}
To overcome pressing food system challenges, academics and civil society actors have called for the development of integrated food policies. Municipalities have increasingly picked up on these calls by developing municipal food strategies. It remains unclear, however, whether and how these commitments have resulted in a genuine institutionalization of food governance across local administrations. We address this gap through an in-depth study of how food governance ideas were institutionalized in the Dutch municipality of Ede, which is considered a frontrunner in municipal food policy. Drawing on discursive institutionalism, we explore how actors, ideas and discourses mutually shaped the institutionalization process. Our analysis shows that food governance ideas were institutionalized following a discursive-institutional spiral of three stages. First, an abstract food profile discourse emerged, which was institutionalized exclusively amongst a small group of policy makers. In the second stage, the discourse shifted to a more elaborate integrated food policy discourse, which was institutionalized across various departments. Finally, a food system discourse emerged, which was institutionalized across an even broader range of policy departments. Our study suggests that integrated food policy can be institutionalized within a relatively short time span. A food strategy, budget and organizational innovations seem key in this process, although they can also be constraining. At the same time, we conclude that retaining a food policy institutionalized remains challenging, as sudden ideational change may cause rapid deinstitutionalization.
\end{abstract}

Keywords Food policy $\cdot$ Food systems $\cdot$ Local governance $\cdot$ Discursive institutionalism $\cdot$ Ideas

\section{Introduction}

Our global food system faces a wide range of sustainability challenges, such as obesity, food waste and climate change. To address these interconnected challenges effectively, scientists and policy makers have stressed the need for integrated food policy (Lang et al. 2009; MacRae 2011; IPES-Food 2017; Moragues-Faus et al. 2017; Candel and Daugbjerg 2019). Integrated food policies emphasize the multifaceted and interrelated nature of food challenges, and address these in a concerted manner (Mendes 2007; Sibbing et al. 2019), thereby integrating health, environmental, social, and

Lara V. Sibbing

lara.sibbing@wur.nl

Jeroen J. L. Candel

jeroen.candel@wur.nl

1 Public Administration and Policy Group, Wageningen University, PO Box 8130, 6700 EW Wageningen, Netherlands economic dimensions to realize sustainable food and nutrition security (Lang et al. 2009; Moragues-Faus and Morgan 2015). Scientists and policymakers therefore consider food policies key for addressing current policy incoherencies, and for fostering synergies that contribute to sustainability (cf. Mendes 2007; Peters 2015; Candel and Pereira 2017).

In response to these calls, an increasing number of municipalities have started to develop integrated food policies. The Milan Urban Food Policy Pact (MUFPP), a voluntary pact signed by almost 200 cities $^{1}$ (MUFPP 2018a), is a good example of this emerging commitment (Candel 2019). The engagement of municipalities in integrated food policy is a promising development, as municipalities have the potential to develop tailor-made and possibly more effective policies, as they benefit from their knowledge of the place, the proximity to the community and the possibility to engage local citizens (Sonnino et al. 2019). The urban can be considered a key space to reshape food system dynamics (Moragues-Faus and

\footnotetext{
${ }^{1} 20-12-2019$
} 
Carroll 2018) and municipalities could therefore be crucial for leading the way to more sustainable food systems.

A common way for a municipality to start with integrated food policy is by developing a municipal food strategy (Mansfield and Mendes 2013; Cretella 2016; Matacena 2016; Hebinck and Page 2017). The strength of these strategies is that they typically target food systems in a holistic manner, targeting environmental, social, health, and economic issues, as well as their interconnections. At the same time, local food strategies have been shown to mainly serve an agenda-setting purpose. They offer no guarantee for institutionally embedding food governance ideas; i.e. institutionalization in the rules, norms, and beliefs of a municipal organization, in the same way economic or health challenges are embedded (Morgan and Sonnino 2010; Sonnino et al. 2019). Such institutionalization is a crucial step for bringing a food strategy beyond paper realities, as it entails the creation of an infrastructure and the conditions to address food issues in the long term.

In spite of the emergence of a rapidly expanding body of literature on both national and municipal food policies in recent years (e.g. Barling et al. 2002; Carey 2013; Lang 1999; MacRae 2011; Mah and Thang 2013; Mansfield and Mendes 2013; Mendes 2007; Rocha and Lessa 2009; Sonnino et al. 2019; Termeer et al. 2018; Yeatman 2003), the institutionalization of these policies across local administrations has largely remained unchartered territory. In this paper we therefore focus on what happens inside the local administration to start addressing this gap. We conduct an in-depth analysis of how food governance ideas were institutionalized within a municipality. The institutionalization of food governance ideas within a municipality requires that food comes to be perceived as a crosscutting concern, in need of an integrated governance approach (Peters 2005; Candel and Pereira 2017). This suggests that the development of ideas about the problem(s) and associated (desired) modes of governance are key to understanding institutionalization processes (Den Besten et al. 2014). Focusing on Ede, one of the first municipalities in the Netherlands with an explicit food strategy, we therefore address the question: how and to what extent were food governance ideas institutionalized within the municipality of Ede?

To study how food governance ideas institutionalized in Ede municipality, we draw on discursive institutionalist (DI) theory (Schmidt 2008; Schmidt 2010).

\section{Discursive institutionalism}

Discursive institutionalism has emerged in the early 2000s as part of the wave of 'new institutionalism' theories, and distinguishes itself from rational choice, historical and sociological institutionalism by focusing on how institutions are shaped and changed - by ideas, through discourses and on how an institutional context again influences (new) ideas through discourses (Schmidt 2008). As such, discursive institutionalism takes actors and the ideas they convey as the conceptual starting point for explaining institutional change and stability. Discursive institutionalist approaches allow for gaining insight in how certain policy ideas and concepts gain legitimacy over others, how struggles over meaning ultimately define and change a policy issue (Den Besten et al. 2014), and how this issue was potentially institutionalized within a polity. This makes DI apt for exploring how ideas shape and influence the institutionalization of food governance ideas within local administrations.

In DI, four concepts are central: ideas, discourses, actors, and institutions. Ideas carry the content of a discourse (Schmidt 2008; Den Besten et al. 2014). Two types of ideas exist: cognitive ideas about how things are done (how it is), and normative ideas that consist of values and attitudes (how it should be) (Schmidt 2008). In practice, cognitive and normative often go hand in hand, making it challenging to draw a clear line between them. Discourse is defined as the communicative process through which actors structure and exchange their ideas, often through contestation with others (Schmidt 2008; Schmidt 2010; Peters 2012, 114; Den Besten et al. 2014). Discourse involves 'the how, when, why and where' ideas are conveyed. Actors are the conveyers of ideas, who thereby shape the discourse. Actors change or maintain, through their discursive abilities and communication, the institutional context - i.e. the situated configuration of rules, norms and beliefs (Scott 2014) - of which they are part. They can negotiate about institutional rules, even while using them, and they can urge others to maintain or change the institutional context (Schmidt 2008; Den Besten et al. 2014). They can do this by promoting their ideas at the expense of the ideas of others (Carstensen and Schmidt 2016). While doing so, actors may exert three types of ideational power: 1) power through ideas, as the capacity of actors to persuade other actors to accept and adopt their views of what to think and do;2) power over ideas, referring to agents' imposition of ideas and the power of actors to resist the inclusion of alternative ideas into a policy-making arena; and 3) power in ideas, involving established hegemony over opinions, and institutions imposing constraints on the ideas actors are allowed to take into consideration (Carstensen and Schmidt 2016). Institutions, in DI, are both given, as the context within which actors think, speak, and act, and contingent, as the results of actors' thoughts, words, and actions (Schmidt 2008).

The process through which discourses, actors, and institutions interact may best be thought of as a 'discursive-institutional spiral' (Den Besten et al. 2014; see Fig. 1). Den Besten et al. (2014) describe this spiral as a "process of institutionalization of discourses on the one hand and the opening up of discourses in response to these institutionalization processes on the other". This spiral consists of two alternating phases. 
Fig. 1 The discursiveinstitutional spiral (Den Besten et al. 2014)

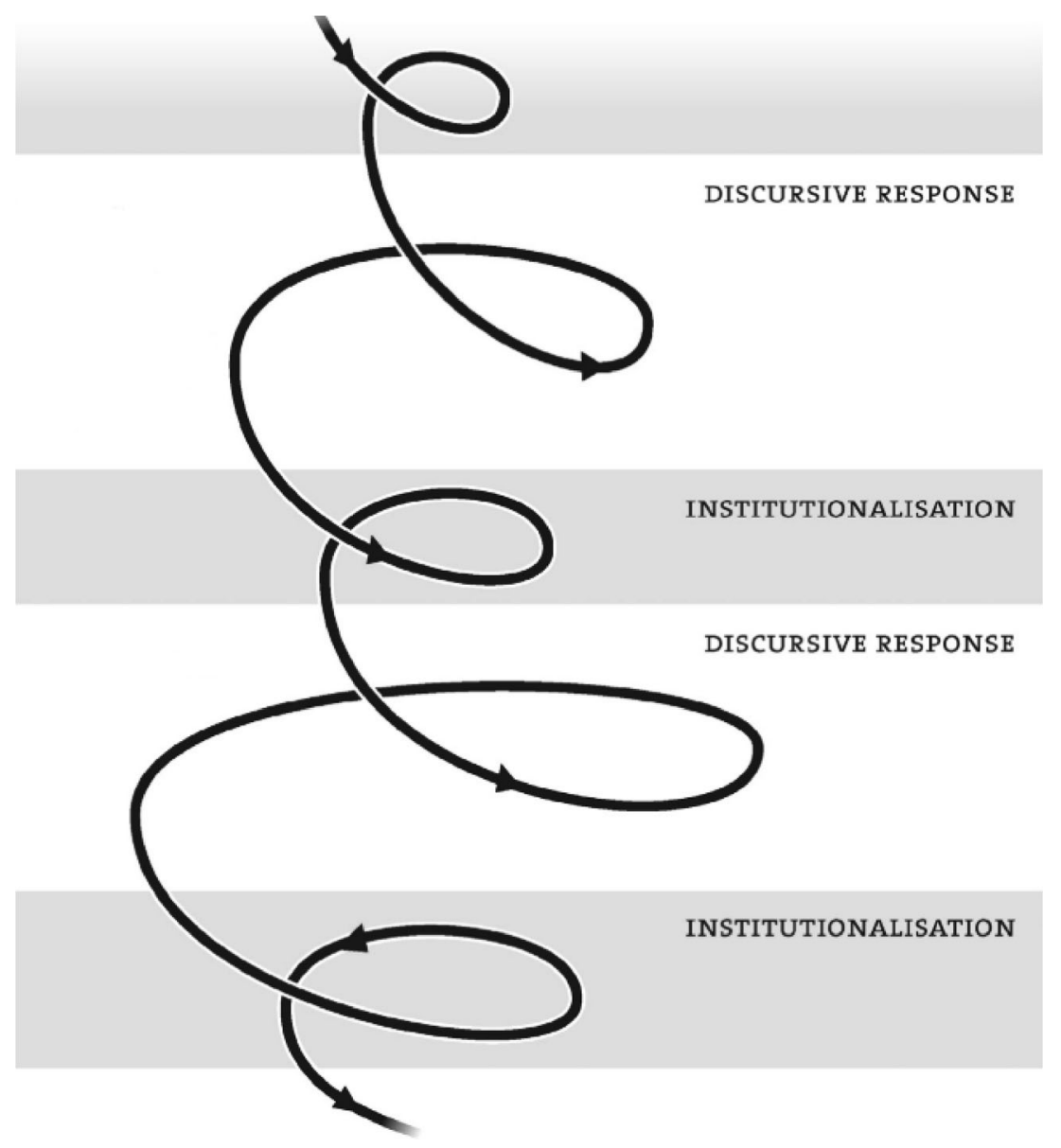

First, expanding constellations of actors reframe existing, and introduce new, ideas, thereby developing a discourse. In a second phase, this discourse narrows down, including and excluding certain ideas, and was (partly) institutionalized in new rules, arrangements, and practices (Lynggaard 2007; Den Besten et al. 2014).

As these two phases alternate, the institutionalized discourse then triggers discussion again, as new actors reframe existing- and introduce new ideas. This discussion again turns into a new discourse, eventually leading to a new instance of institutionalization (Den Besten et al. 2014). It should be kept in mind that the discursive-institutional spiral is a simplified model of reality; in practice institutionalization is not a linear process.

As Ede municipality has made considerable efforts to introduce an integrated food policy approach, we expect a discursive-institutional spiral to have been at work within the municipal organization, with an integrated food policy discourse institutionalizing across a wide range of municipal departments. In practice, this would mean that each department would address the food issues that relate to its policy field, e.g., the health department promoting healthy diets, or the sustainability department promoting food waste reduction. Following Den Besten et al. (2014), we investigated how a discursive-institutional spiral with regard to food governance ideas has developed for the case of Ede and what the characteristics of this spiral were. We discerned (cycles of) the two phases of the discursive-institutional spiral: i) institutionalization, in which ideas were institutionalized in policy arrangements and social practices, and ii) discursive responses, in which the discourse opens up again, through new actors and ideas.

\section{Methods}

Given the lack of existing scholarship on municipal food policy institutionalization, we conducted an exploratory single- $n$ case study, aimed at obtaining an in-depth understanding of the discursive-institutional spiral process. We opted for a participatory approach to be able to study interactions between actors, their ideas and discourses from up close. This means that over the course of the research, the main author was part of Ede's municipal food policy team and made fieldnotes on her observations, while contributing to the municipality's food policy.

Ede has about 116.000 inhabitants (Gemeente Ede 2019) and is one of the largest Dutch municipalities in surface area. 
In addition to an urban center, Ede also includes a vast rural area, which is characterized by intensive livestock farming. Ede is part of the FoodValley region: eight adjacent municipalities that harbor a large number of agri-food businesses and agri-food knowledge institutes, such as the University of Wageningen. The Netherlands is a decentralized unitary state, in which food policy-related issues have traditionally been dealt with at national, provincial as well as supranational levels. Until now, no overarching national or provincial food policies have been adopted. Municipalities in the Netherlands do not have many explicit food related competences, but they are responsible for a broad range of issues that impact food systems, including zoning, organizing and issuing permits for local initiatives and events, social policy, youth care, housing, infrastructure, and local environmental protection. Also, municipalities are allowed to address any topic they wish through the 'open housekeeping' principle, meaning that they can adopt interventions in any field they deem important as long as this does not conflict with other jurisdictions' efforts. Municipalities can make use of this principle to develop food policy and address food system issues, though not many of them have done so yet (Sibbing et al. 2019).

Ede is one of the few Dutch municipalities that has addressed a wide array of food-related challenges across sectoral policy efforts through a food strategy (Sibbing et al. 2019). Moreover, Ede has strongly focused on embedding food governance ideas in its organization by using a politically binding governance approach that includes a food program, -team and -alderman (elected official) (Zweynert 2017; MUFPP 2018b). In 2015, the Ede city council officially adopted the food strategy (Gemeente Ede 2015) and in 2017 Ede won an international award for its integrated food policy and governance approach (MUFPP 2018b).

The institutional context under study, we delimited as the municipality's executive organization, consisting of the Board of Mayor and Aldermen and the civil service. As the executive organization does not operate in a vacuum, interactions with the Ede city council and civil society were included in the analysis when these proved explanatory for the internal discursive institutionalization process. Our analysis covers the period from 2010 through 2018, starting from the first time a food discourse emerged: following the 2010 municipal elections.

We used four data sources: i) field notes from the main author's reflective journal $\log (n=88$, collected between May 2017-March 2018); ii) focus group transcripts $(n=3)$; iii) policy documents $(n=32)$; and iv) additional written sources such as press releases and web pages. As the main author of this paper works as a food policy adviser in Ede's municipal food team, field notes covered formal and informal meetings with municipal officials, conversations, events and written materials that the main author came across in her daily work. As a second source, three focus groups were organized, each with a different group of municipal officials, to ensure a representative range of perspectives: i) members of the Ede food team; ii) civil servants who collaborated most frequently with the food team (e.g. the sustainability manager and the economic affairs officer); iii) the top management of the municipality (the responsible alderman and two managers). All focus groups were held in 2018, consisted of 3-5 participants, and focused on the development of Ede's integrated food policy and governance approach between 2010 and 2018. The main author of this paper took on a facilitating role in the focus groups, using five open questions to guide the discussion. Third, to complement the two other data sources, we collected all municipal planning and control (P\&C) cycle documents, which comprise three documents per year and two coalition agreement documents in election years. $\mathrm{P} \& \mathrm{C}$ documents provide insight into the main policy course of a municipality. To gain more detailed insight, we also included three specific food policy documents (Gemeente Ede 2012; Gemeente Ede 2015; Gemeente Ede 2017). Additional written sources were consulted to verify findings where necessary.

Texts of field notes, focus group transcripts and policy documents were analyzed for evidence of ideas, involved actors and accounts of discursive interactions. Texts were analyzed for both their content and their function as meaning-making devices, e.g., communicating policy beliefs (Gillard 2016). We reconstructed discourses, coalitions, rules and, eventually, the different phases of the discursive-institutional spiral, through a continuous, iterative comparison of the insights obtained through the four data sources. Importantly, we acknowledge that while the main author's engagement as participant-observer gives us a unique perspective, it also creates the potential for bias. When combining the roles of researcher and policymaker, it is key to constantly remain aware of one's positionality as fulfilling two roles simultaneously (Yanow 2007). In participatory research, the way to do this and hence to avoid bias is through reflexivity (Yanow 2007; Moragues-Faus 2020, 114-115). We therefore performed several reflective practices. First, we followed Yanow $(2009,279)$ in acknowledging four moments of interpretation: 1; experience, 2; interpretation 3; analyzing and 4; reading. Experiences were written down immediately, while interpretation, analysis and reading were done at a later moment to allow the main author to take a step back from the research context again. Second, continuous discussions about data collection and interpretation between the authors were held. Third, we organized individual member checks with the food alderman and three civil servants. Fourth, we presented preliminary findings in the focus groups and used participants' feedback to refine findings and conclusions.

\section{Results}

\subsection{0-2012: Emergence of the food profile discourse}

The first signs of a food discourse emerging within Ede municipality date back to 2010 , with that year's municipal 
elections marking a clear starting point. For the first time, confessionalist (Christian) parties received a minority of the 39 council seats in Ede, and several new aldermen entered the Board of Mayor and Aldermen. They argued that the municipality needed a future vision to foster its development. This idea was new, as Ede had no tradition of developing overarching future visions. Policy makers from the departments of Strategy \& Research and City Marketing subsequently consulted citizens, NGO's, and entrepreneurs. These actors proposed a broad variety of ideas to improve Ede, but the board of Mayor and Aldermen were missing one overarching focus. One of the new aldermen proposed 'food' as the overarching focus, arguing it was both characteristic for the agrifood knowledge-intensive FoodValley region, and something every citizen could relate to. The other members of the Board of Mayor and Aldermen agreed and together they formulated the following aim: food as the focus theme to better position, and create a distinctive profile for Ede, by developing the FoodValley region into the agri-food center of Europe. When policy makers from the Strategy \& Research and the City Marketing departments also found this idea a good addition to the vision, it became the core of the first food-related discourse. We label it the food profile discourse. The use of the English term food, instead of the Dutch term voedsel, was characteristic for this discourse, representing the international economic orientation. As this discourse emerged in a rather top-down way, support for it remained limited to the Board of Mayor and Aldermen and policy makers from the Strategy \& Research and the City Marketing departments. Consequently, though the involved actors might have occupied powerful positions, they did not succeed in conveying their ideas at this stage.

\subsection{2: The first food discourse being institutionalized in a key policy document}

Following the emergence of the food profile discourse, 2012 witnessed a first institutionalization phase, when the discourse was formalized in a new municipal vision document 'Vision 2025: Ede choses food' (Gemeente Ede 2012). This document was officially adopted by the city council and therefore gained a politically binding status. The main ambition of the vision was broad: to become an agri-food top region with a distinctive profile by 2025 , particularly focusing on the relationship between food and health, as well as the economic opportunities resulting from fostering the food sector (Gemeente Ede 2012). Shortly after, Ede won the bid to develop the World Food Centre (WFC), an interactive exposition center about agri-food, which the Board of Mayor and Aldermen used to further legitimize and advocate the food profile discourse. A clear example of the food profile discourse can be found in the 'Vision 2025: Ede choses food':
In 2025, FoodValley is the agri-food center of Europe. A top sector in a top region. A new economic engine for Ede. Together with Wageningen UR and many other partners we play our part. FoodValley gives Ede a unique profile within the Netherlands (Gemeente Ede 2012, 7).

At this stage, the food profile discourse was institutionalized mainly among the same departments that had been involved in shaping it. Institutionalization therefore remained limited to the beliefs of the Board and civil servants in the involved departments, while no new norms, rules or organizational innovations were adopted.

\subsection{2-2014: A critical response and a discourse shift}

Soon after the vision document was adopted, the discourse opened up again, as critics, both within the administration and in the city council, argued the food profile discourse remained too abstract. A discussion emerged on the concrete goals the food vision's ambition would translate into, and on how to operationalize these. This discussion was mainly held within two parallel groups. A newly formed municipal food workgroup was led by the city marketeer and consisted of policy makers from predominantly three strategic departments: Strategy \& Research, Economic Affairs, and Communication. The second group consisted of the highest municipal managers. A variety of potential food goals were proposed, but, at its core, the discussion was about two diverging normative ideas: fostering a stronger, more innovative agri-food business sector on the one hand, versus stimulating healthy and sustainable food and short food chains on the other. A third, more cognitive idea found wide resonance among all involved actors and connected them: food as a promising tool for better connecting a wide range of siloed policy efforts.

To add focus and concretize Ede's food ambition, actors involved in the discussion increasingly called for a specific municipal food strategy. In 2013, an intern (this paper's lead author) and consultants from Wageningen University and Research were therefore asked to develop a strategy. They introduced the new idea of a food strategy as a holistic approach for improving the food system in and around a city, a theoretical concept originating from food policy sciences (Cretella 2016). Food system stakeholders and citizens were consulted and introduced a wide range of food related ideas. In 2014, cultural, culinary and local food ideas gained ground in this food strategy discussion, as Ede became Dutch 'capital of taste' that year, which led to a range of events on local food and food culture.

The food strategy process also revealed that becoming the agri-food center of Europe meant something different to actors 
in each municipal department, when they were consulted to synthesize the proposed ideas into main policy goals. The Economic Affairs department advocated the idea of facilitating the agri-food sector to boost the economy, the Social Affairs department advocated the idea of educating citizens with a small budget on healthy nutrition and of food education for children, and the Spatial Development department advocated the idea of more urban agriculture in neighborhoods. As the process coordinators wanted a widely supported strategy, all ideas were 'piled up' and no trade-offs were made. Dynamics between the departments were therefore friendly and without power struggles, with a wait-and-see mentality among actors towards this new concept of a food strategy.

The proposed ideas were so manifold and normatively varied, that involved actors agreed to synthesize ideas into the main idea of food as one crosscutting issue with a wide scope, touching upon both economic and social issues, that should be governed through an integrated approach. We call this the integrated food policy discourse. It comprised a wide spectrum of policy ideas, ranging from stimulating school gardens, to facilitating knowledge exchange between agri-food businesses, as the Ede food vision document shows:

1. Enhancing the economic strength of Ede: competitiveness with other cities and regions and attractiveness for companies and knowledge institutions, students, visitors (business and touristic) and (future) inhabitants.

2. Enhancing the social strength of Ede: enhancing meeting and connecting, strengthening the bond between city and countryside and facilitating and stimulating awareness around healthy and sustainable food (Gemeente Ede 2015, 12).

Compared to the food profile discourse, the integrated food policy discourse was less abstract, but much broader in terms of substantive scope.

\subsection{4-2015: A second and more comprehensive institutionalization phase}

Following the emergence of the integrated food policy discourse, a second, and more comprehensive food institutionalization phase can be distinguished between 2014 and 2015 . Upon elections in 2014, the political coalition changed. The new coalition found the food strategy important and wanted to take thorough steps to implement it. Five organizational innovations were therefore introduced: i) the position of food alderman; ii) the adoption of a politically binding food strategy; iii) the allocation of a food budget; iv) a food strategy implementation program; and v) eventually also a food team.

The position of food alderman was a direct outcome of the Board of Mayor and Aldermen's 2014 portfolio negotiations, in which the Board unanimously designated food as a distinctive portfolio issue. The policy issue of 'food' was assigned to a newly elected alderman, which resulted in 'food' receiving a responsible elected official and a stable spot on the municipal agenda. This made Ede the first municipality in the Netherlands with a 'food alderman'. The food strategy 'Visie Food!' was adopted by the city council in 2015 , as the final product of the development process that had started in 2013. This made it one of the few food strategies in the Netherlands with a politically binding status (Sibbing et al. 2019). The food strategy reflected the broadness of the integrated food policy discourse: goals were manifold (19 goals) and differed greatly in topic and abstractness. The council also assigned a budget of several million euros to implement the food strategy over the course of 5 years. This budget was drawn from a newly created investment fund, thereby exempting the municipality from - potentially hard - negotiations about reallocating existing budgets, as the (sizable) budget did not have to be drawn from regular municipal finances. The food budget was designated to develop an implementation program for the food strategy and implement it between 2016 and 2019. The first annual food program was developed in 2015, further concretizing the strategy with sub goals and targets. The program was developed and managed by the food team, which consisted of a newly hired food program manager, a project assistant and the former intern, who was now hired as a food policy maker. The food team provided the food strategy and program with executive capacity and expertise.

Through these five governance innovations, the integrated food policy discourse gained an institutional place in the municipal organization.

\subsection{5-2016: Internal criticism on the new food discourse}

In 2015 the food discourse opened up again when the food team started implementing the food program they had developed. The team sought collaboration with other municipal departments, such as the Spatial Planning department and the district social workers team. In the broad integrated food policy discourse, civil servants from several departments identified particular food governance ideas they could relate to, and adopted these in their own policy domains. However, the integrated food policy discourse also encountered resistance among many civil servants that were requested to contribute to implementing the food program. These new actors exercised their power over ideas and voiced three critical ideas: i) the food strategy is unclear, unfocused, and consists of a range of 'piled up' ideas, rather than a concerted whole; ii) 'food' is no pressing policy concern, but rather an elitist city marketing concern, dealing with issues like food festivals and the World Food Centre; iii) 'food' is not a municipal, but rather a national or EU responsibility. 
In several ways these ideas led to civil servants not feeling ownership over issues and perceiving them as the responsibility of the food team. Primarily, as civil servants perceived the strategy to be unclear and non-urgent, they also found it unclear how food governance ideas linked to their own policy domain. This unclarity was intensified, as the actors advocating the discourse increasingly emphasized the holistic character of the food strategy over its substantial aims. As a result, it was unclear to civil servants what their role were to be in addressing food challenges and what this would imply for their own work duties and routines, resulting in a lack of ownership. This feeling was further strengthened as they felt the food team was imposing on them to address food challenges, instead of involving them in the process and providing them with the assistance and tools to tackle challenges autonomously. In most departments civil servants therefore did not support the integrated food policy discourse and did not adopt food governance ideas.

\subsection{6-2017: A discourse shift leading to the third institutionalization phase}

In response to the criticism on the food strategy, the food team -meanwhile consisting of seven members- organized a discussion on the main municipal ambition regarding 'food' among its members and one of the top managers. This discussion led to a discourse shift, that subsequently resulted in a crucial institutionalization phase in 2017. In the discussion, the team reflected on 'the higher purpose' of the food strategy and explicitly agreed that improving the food system, not improving the municipality's profile, were to be its primary goal. As a result, a new food discourse emerged, stressing the achievement of a healthy and sustainable food system for everyone in Ede, by adopting a food system's approach. We call this the food system discourse. This discourse, initially supported by a relatively small group of actors (the food team) was subsequently institutionalized widely across the municipality through two successive steps. First, the food team formalized it in a food strategy 2.0 , in which they synthesized the initial 19 food strategy goals into six concrete and concise sub goals: healthy people, healthy food environment, sustainable food consumption, short food chains, a robust agri-food sector and the use of a food system's governance approach (Gemeente Ede 2017). This strategy was clear, as food ideas were more elaborate and explicit, including sub goals, targets and indicators. The sub goal healthy food environment for instance, was formulated as follows:

In Ede, we are creating a healthy food environment that helps people make healthy diet choices as much as possible. We focus on ensuring a healthy food supply in public facilities, food teaching at every primary school and a public space that stimulates healthy behavior.
Specific examples of this include ensuring healthy food in the hospital or the sports canteen, installing water fountains at school and organizing lessons on how to tend a vegetable patch, and providing edible greenery and urban agriculture in the district (Gemeente Ede 2017).

Subsequently, civil servants in more departments, such as Public Affairs, Real Estate Management, and Rural Affairs, gradually started addressing food governance ideas in speeches, policies, and informal narratives. An attractive factsheet of the new food strategy played a key role, as it served to communicate issues and goals clearly and in this way facilitated civil servants in adopting food governance ideas. Hence, through the more elaborate and specific food system discourse, food governance ideas were being further institutionalized in Ede.

\subsection{7-2019: Focus on the continuity of integrated food policy}

From 2017 onwards, awareness grew that although integrated food policy had been institutionalized to a considerable extent across the political top and key policy departments, this idea remained vulnerable to possible deinstitutionalization in the future. Organizational innovations had been in place for several years now, and food policy was gaining ground within the municipality. The continuity of these organizational innovations remained delicate though, as the investment fund (covering the resources of the food budget) was to end after 2019 and, consequently, the food budget and personnel capacity had to be reduced. As a result, in 2018 and 2019, the highest municipal managers and the food team continuously discussed how to continue municipal food policy in the future and how to prevent it from losing ground again on the municipal agenda. They introduced two ideas to prevent this from happening, that became prominent in the broader discourse. First, food was to be embedded as a crosscutting policy issue throughout the entire municipal organization, through further adoption by the existing departments. Second, Ede was to retain its acquired position as integrated food policy frontrunner, by continuing to innovate and create societal impact, and through addressing more politically contested issues, such as the protein transition, entailing a shift from meat- to plant-based diets. In 2019, the dominating food system discourse therefore shifted slightly again, focusing more on the continuity of integrated food policy in the future.

\section{Discussion}

In this study we aimed to explore to what extent and how food governance ideas were institutionalized within the municipal 
administration of Ede. Figure 2 presents an overview of the different phases and the corresponding key actors and main ideas in the institutionalization process. Four findings particularly stand out as relevant beyond the case of Ede.

First, our study shows that food governance ideas can be institutionalized considerably within a relatively short time span and that institutional innovations play a key role in this process. In Ede, a formal food strategy, associated budget, and organizational innovations such as the creation of a specialized team proved imperative. These institutional changes served to keep food governance ideas on the agenda, formalized their status as a crosscutting policy issue, and guaranteed
Fig. 2 The discursiveinstitutional spiral of food governance ideas at the municipality of Ede between 2010 and 2018 (inspired by Den Besten et al. 2014)

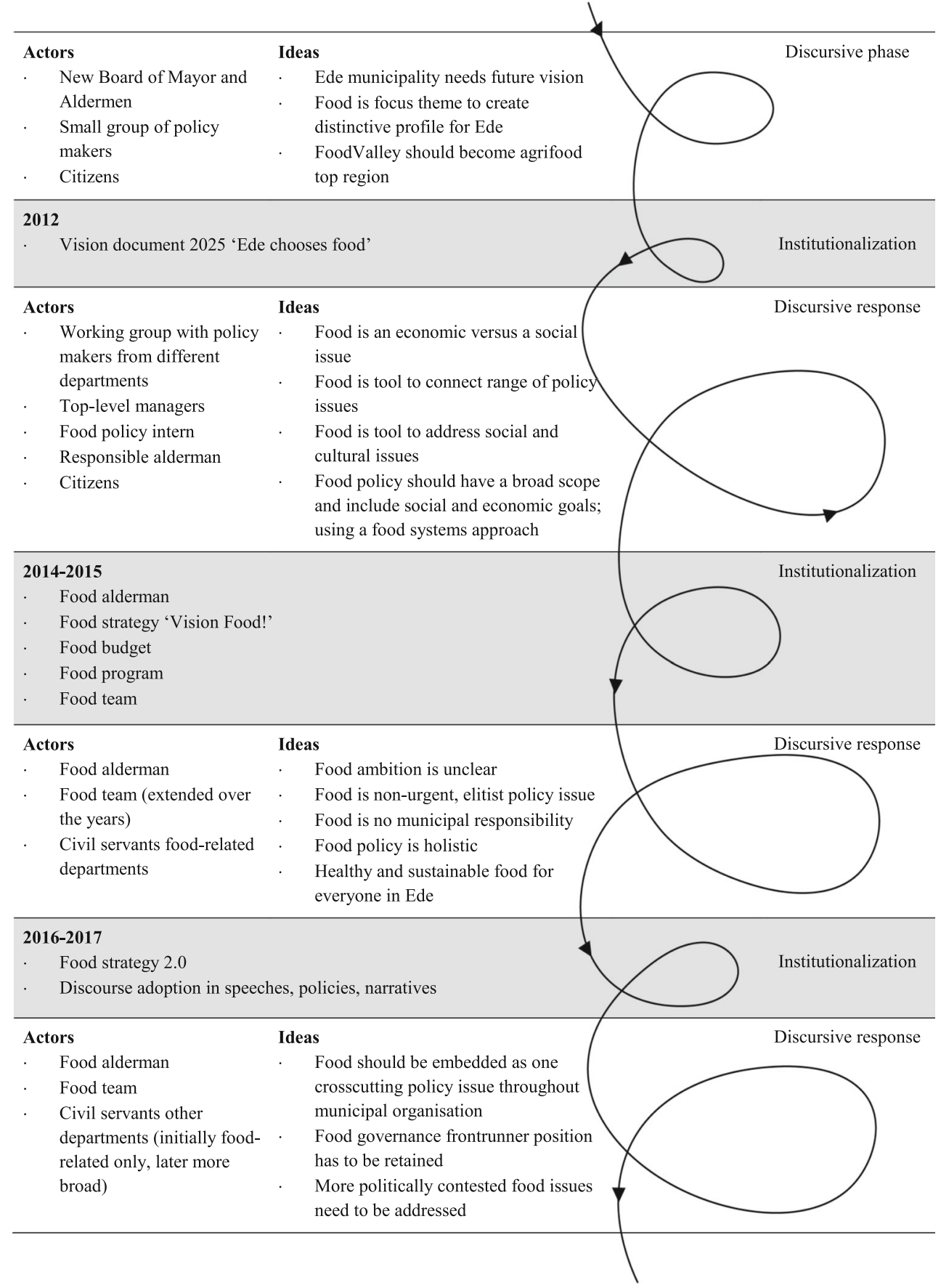


an organizational 'home' within the administration. In this way, food policy efforts could be continued after elections, which have been identified as a disrupting force in previous studies (Yeatman 2003; Rocha and Lessa 2009; Sonnino 2009; Halliday 2015, 95). Our findings correspond with previous calls for institutional reform to sustain integrated food policy efforts (Termeer et al. 2018), e.g., allocating (financial) resources (Morgan and Sonnino 2010; Shey and Belis 2013), the official adoption of a specific food strategy (Mendes 2008), and the creation of specific units, agencies and staff positions (Mendes 2008; Rocha and Lessa 2009; Shey and Belis 2013; Coplen and Cuneo 2015). In Toronto, for example, assigning designated food policy staff in a similar way guaranteed consistent administrative leadership and organizational stability, keeping food system goals on the radar and avoiding lapses in activity (Dahlberg 1994; Borron 2003). In Vancouver as well, the adoption of a 'Food Action Plan' provided food policy efforts with an official legal mandate, which subsequently led to the allocation of resources and human capacity (Mendes 2008).

Second, at the same time, our analysis shows that institutional reform resulting in centralization of policy making and implementation can also inhibit the institutionalization across municipal departments, as civil servants may come to see food policy efforts as 'already being taken care of', or 'not my responsibility'. At times, this made food policy in Ede an 'island' in the municipal organization, rather than being the desired 'web' through which food governance ideas would become embedded in policy domains. It therefore seems important to complement centralizing reforms with mechanisms that keep other parts of the administration involved, e.g., by staffing a food team with civil servants that continue working in existing departments.

Third, somewhat paradoxically, the relatively broad resonance of the food discourse in Ede over time may partly be attributed to its high level of abstraction in the first years. This allowed for a wide range of actors to interpret and identify with the food agenda in line with their own backgrounds. This finding corresponds with previous observations that concepts such as 'food security' may come to serve as 'consensus frames' (Candel et al. 2014) or 'coalition magnets' (Sharma and Daugbjerg 2019). At a later stage, the involvement of these diverse actors contributed to realizing more focus, as they brought in their own ideas and exchanged these with others. Thus, contrary to cities that explicitly developed food policies to enhance food systems outcomes from the start on, such as Bristol (Carey 2013) or Belo Horizonte (Rocha and Lessa 2009), Ede shows that a city does not need to start off with this aim. A municipality can get food governance ideas on the agenda by using a different frame (such as city marketing), while eventually adopting an integrated food policy approach to enhance its food system. At the same time, the abstractness of the discourse at times also proved constraining, as actors came to see the food policy efforts as vague. In an extreme case, this may result in a lacking sense of urgency and ownership, leading to actors becoming resistant and paralyzed (Termeer et al. 2018). We therefore pose that a broad discourse should not be used as an excuse to avoid making clear-cut political decisions; integrative action is not the same as layering a range of issues, but requires setting clear goals and directions.

Fourth, although our study shows that integrated food policy ideas can be institutionalized to a considerable extent within a relatively short time span, it also shows that a food policy can remain relatively vulnerable to possible deinstitutionalization in the (near) future. The challenge of retaining integrated food policy efforts has been acknowledged in the literature, e.g., as described by Rocha and Lessa $(2009,396)$ for the Brazilian city of Belo Horizonte:

While changes in the city administration always bring uncertainties concerning policy priorities, at the food department such uncertainties involve its very existence; the continuation of its integrated food policy. Governments can come and go without questioning the need for an education policy, or a health policy. Food policy is not yet at this level in Belo Horizonte, despite more than 15 years of success. As a consequence, the food department's staff spend a lot of time rearguing the case for an integrated food policy.

Similar tendencies could be observed in Ede, for which a key reason is that food governance ideas have not (yet) been institutionalized in departments that are responsible for the delivery of public services, such as public space maintenance or district work. The involvement of such departments would help to further embed integrated food policy and would be essential for realizing impact on the ground in cities. A possible way to prevent deinstitutionalization in municipalities would be to adopt food policy as a formal municipal responsibility in local or national legislation. In case of the latter, this would require greater coordination of local food policy mandates at national level. Rapidly realizing formal institutions within a municipality, such as written mandates or budgeting requirements, would foster institutionalization too. 
Finally, in terms of the theoretical approach adopted in this study, we found that the discursive-institutional spiral theory (Den Besten et al. 2014) proved to be useful for studying food policy, as it allowed for the systematic analysis of the underlying dynamics of food policy institutionalization within an administration. As we studied one case only, the key insights discussed above primarily have a theorybuilding function; follow-up comparative studies of local food policy efforts across different contexts would allow for further investigating diversity and similarities in institutionalization processes across administrations. Additionally, it would be valuable to study whether and how such institutionalization processes affect policy implementation on the ground, e.g., in service delivery. Whereas the institutional embeddedness of food policy efforts may be an important prerequisite, it is through the actions of street-level bureaucrats that ultimate target groups come to be affected. What integrated food policy means to them and how it shapes their practices largely remains unchartered territory.

For cities interested in food policy we can draw several lessons. First, our study shows that a city does not have to be a metropole to do successful food policy work. While local food policy research has mostly focused on large cities (e.g. Toronto, New York, Belo Horizonte), ours is one of the first analyses of a medium-size city. The hypothesis we derive from this is that governance capacity is a much stronger determinant to a city's successful food policy institutionalization than a city's size as such. Second, to start up food policy initiatives, it seems key to have a few dedicated ideational leaders working within the municipality. This does not necessarily have to result in a full-blown food systems approach from the start. The case of Ede shows that loose agenda items (e.g. a stronger city profile or children's health) can serve as a stepping stone for developing a genuine food systems approach and associated governance agenda.

While scholars and policymakers alike laude food policy as the key to overcome food and nutrition security issues in both developing and developed countries, our study shows that institutionalization is key for bringing food policy beyond paper realities. An integrated food policy therefore, is only as good as its institutionalization into the government that developed it. Ultimately, we also need to look beyond institutionalization processes, to assess how food policy integration contributes to more effective governance of food insecurity and food system sustainability.

Acknowledgements We would like to thank the municipality of Ede, the Netherlands, for facilitating the main author's $\mathrm{PhD}$ research, of which this paper is part. We also want to thank Iris Vermaas for the visual design of Fig. 2. The analysis and results presented in the paper are those of the authors and do not represent the views of Ede municipality.
Authors contribution Lara V. Sibbing: Conceptualization, Methodology, Investigation, Formal analysis, Writing - original draft, Validation, Visualization, Project administration.

Jeroen J.L. Candel: Conceptualization, Methodology, Validation, Writing - review \& editing, Supervision.

\section{Compliance with ethical standards}

Conflict of interest The authors declare that they have no conflict of interest.

Open Access This article is licensed under a Creative Commons Attribution 4.0 International License, which permits use, sharing, adaptation, distribution and reproduction in any medium or format, as long as you give appropriate credit to the original author(s) and the source, provide a link to the Creative Commons licence, and indicate if changes were made. The images or other third party material in this article are included in the article's Creative Commons licence, unless indicated otherwise in a credit line to the material. If material is not included in the article's Creative Commons licence and your intended use is not permitted by statutory regulation or exceeds the permitted use, you will need to obtain permission directly from the copyright holder. To view a copy of this licence, visit http://creativecommons.org/licenses/by/4.0/.

\section{References}

Barling, D., Lang, T., \& Caraher, M. (2002). Joined-up food policy? The trials of governance, public policy and the food system. Social Policy and Administration, 36, 556-574. https://doi.org/10.1111/ 1467-9515.t01-1-00304.

Besten, D., Willem, J., Arts, B., \& Verkooijen, P. (2014). The evolution of REDD+: An analysis of discursive-institutional dynamics. Environmental Science and Policy, 35, 40-48. https://doi.org/10. 1016/j.envsci.2013.03.009.

Borron, S. M. (2003). Food policy councils: Practice and possibility. Community report. 1-29. Eugene, United States. Retrieved from www.lanefood.org/foodpolicycouncils\%0Ahttps://assets.jhsph.edu/clf/ mod_clfResource/doc/Food Policy Councils Practice and Possibility.pdf.

Candel, J. J. L. (2019). What's on the menu? A global assessment of MUFPP signatory cities' food strategies. Agroecology and Sustainable Food Systems. Taylor \& Francis, 1-28. https://doi.org/ 10.1080/21683565.2019.164.

Candel, J. J. L., and Daugbjerg, C. (2019). Overcoming the dependent variable problem in studying food policy. Food Security, 12(1). https://doi.org/10.1007/s12571-019-00991-2.

Candel, J. J. L., \& Pereira, L. (2017). Towards integrated food policy: Main challenges and steps ahead. Environmental Science and Policy, 73, 89-92. https://doi.org/10.1016/j.envsci.2017.04.010.

Candel, J. J. L., Breeman, G. E., Stiller, S. J., \& Termeer, C. J. A. M. (2014). Disentangling the consensus frame of food security: The case of the EU Common Agricultural Policy reform debate. Food Policy, 44. Elsevier Ltd, 47-58. https://doi.org/10.1016/j.foodpol.2013.10.005.

Carey, J. (2013). Urban and community food strategies. The case of Bristol. International Planning Studies, 18, 111-128. https://doi. org/10.1080/13563475.2013.750938.

Carstensen, M. B., \& Schmidt, V. A. (2016). Power through, over and in ideas: Conceptualizing ideational power in discursive institutionalism. Journal of European Public Policy, 23. Taylor \& Francis, 318337. https://doi.org/10.1080/13501763.2015.1115534.

Coplen, A., \& Cuneo, M. (2015). Dissolved: Lessons learned from the Portland Multnomah food policy council. Journal of Agriculture, 
Food Systems, and Community Development, 5, 91-107. https://doi. org/10.5304/jafscd.2015.052.002.

Cretella, A. (2016). Urban food strategies. Exploring definitions and diffusion of European cities' latest policy trend. In T. K. Marsden (Ed.), Metropolitan Ruralities (research in rural sociology and development, Vol. 23) (pp. 303-321). Bingley: Emerald Group Publishing Limited. https://doi.org/10.1108/S1057-192220160000023013.

Dahlberg, K. A. (1994). Food Policy Councils: The experience of five cities and one county. Paper presented at the Joint Meeting of the Agriculture Food and Human Values Society and the Association for the Study of Food and Society. Tucson, United States, 9-12 June.

Gemeente Ede. (2012). Visie Ede 2025: Ede kiest voor food. Ede, The Netherlands. Retrieved fromhttps://ede.raadsinformatie.nl/ document $/ 575428 / 2 \#$ search $=\% 22$ visie $\% 202025 \% 202012 \% 22$.

Gemeente Ede. (2015). Visie food! In uitvoering 2015-2020: de foodvisie van Ede. Ede, The Netherlands. Retrieved from http:// docplayer.n1/21566850-Visie-food-in-uitvoering-2015-2020-defoodvisie-van-ede-9-juni-2015.html.

Gemeente Ede. (2017). Food policy in Ede. Ede, The Netherlands. (Unpublished).

Gemeente Ede. (2019). Ede in cijfers: totaal aantal inwoners 2019. Ede, The Netherlands. Retrieved from https://ede.incijfers.nl/dashboard/ ede-incijfers/bevolking/.

Gillard, R. (2016). Unravelling the United Kingdom's climate policy consensus: The power of ideas, discourse and institutions. Global Environmental Change, 40. Elsevier ltd, 26-36. https://doi.org/10. 1016/j.gloenvcha.2016.06.012.

Halliday, J. J. (2015). A new institutionalist analysis of local level food policy in England between 2012 and 2014. London: City University London. Retrieved from https://openaccess.city.ac.uk/id/eprint/13768.

Hebinck, A., \& Page, D. (2017). Processes of participation in the development of urban food strategies: A comparative assessment of Exeter and Eindhoven. Sustainability, 9. Multidisciplinary digital publishing institute, 931. https://doi.org/10.3390/su9060931.

IPES-Food. (2017). Unravelling the food-health Nexus: Addressing practices, political economy, and power relations to build healthier food systems. Brussels, Belgium. Retrieved from http://www.ipesfood.org/_img/upload/files/Health_FullReport(1).pdf.

Lang, T. (1999). The complexities of globalization: The UK as a case study of tensions within the food system and the challenge to food policy. Agriculture and Human Values, 16, 169-185. https://doi. org/10.1023/a:1007542605470.

Lang, T., Barling, D., \& Caraher, M. (2009). Food policy: Integrating health, environment and society (1st ed.). Oxford: Oxford University Press.

Lynggaard, K. (2007). The institutional construction of a policy field: A discursive institutional perspective on change within the common agricultural policy. Journal of European Public Policy, 14. Routledge, 293-312. https://doi.org/10.1080/13501760601122670.

MacRae, R. (2011). A joined-up food policy for Canada. Journal of Hunger \& Environmental Nutrition, 6. Taylor \& Francis Group, 424-457. https://doi.org/10.1080/19320248.2011.627297.

Mah, C. L., \& Thang, H. (2013). Cultivating food connections: The Toronto food strategy and municipal deliberation on food. International Planning Studies, 18, 96-110. https://doi.org/10. 1080/13563475.2013.750941.

Mansfield, B., \& Mendes, W. (2013). Municipal food strategies and integrated approaches to urban agriculture: Exploring three cases from the global north. International Planning Studies, 18, 37-60. https://doi.org/10.1080/13563475.2013.750942.

Matacena, R. (2016). Linking alternative food networks and urban food policy: A step forward in the transition towards a sustainable and equitable food system? International Review of Social Research, 6 , 49-58. https://doi.org/10.1515/irsr-2016-0007.

Mendes, W. (2007). Negotiating a place for 'sustainability' policies in municipal planning and governance: The role of scalar discourses and practices. Space and Polity, 11. Routledge, 95-119. https://doi. org/10.1080/13562570701406683.

Mendes, W. (2008). Implementing social and environmental policies in cities: The case of food policy in Vancouver, Canada. International Journal of Urban and Regional Research, 32. Blackwell publishing ltd, 942-967. https://doi.org/10.1111/j.1468-2427.2008.00814.x.

Moragues-Faus, A. (2020). Action research as a tool to measure progress in sustainable food cities: enacting reflexive governance principles to develop indicators. In A. Blay-Palmer, D. Conaré, K. Meter, A. Di Battista, \& C. Johnston (Eds.), Sustainable food system assessment: Lessons from global practice (1st ed., pp.111-129). London: Routledge.

Moragues-Faus, A., \& Carroll, B. (2018). Reshaping urban political ecologies: An analysis of policy trajectories to deliver food security. Food Security, 10. Food security, 1337-1351. https://doi.org/10. 1007/s12571-018-0855-7.

Moragues-Faus, A., \& Morgan, K. (2015). Reframing the foodscape: The emergent world of urban food policy. Environment and Planning A, 47, 1558-1573. https://doi.org/10.1177/0308518X15595754.

Moragues-Faus, A., Sonnino, R., \& Marsden, T. (2017). Exploring European food system vulnerabilities: Towards integrated food security governance. Environmental Science and Policy, 75, 184-215. https://doi.org/10.1016/j.envsci.2017.05.015.

Morgan, K., \& Sonnino, R. (2010). The urban foodscape: World cities and the new food equation. Cambridge Journal of Regions, Economy and Society, 3, 209-224. https://doi.org/10.1093/cjres/rsq007.

MUFPP. (2018a). Signatory cities - Milan urban food policy pact. https:// www.milanurbanfoodpolicypact.org/signatory-cities/. Accessed 20 Dec 2019.

MUFPP. (2018b). Ede: A promising shift in food governance. https:// www.milanurbanfoodpolicypact.org/wp-content/uploads/2018/07/ Brief-4-Ede.pdf.Accessed 20 Dec 2019.

Peters, B. G. (2005). The Search for Coordination and Coherence in Public Policy: Return to the Center? Unpublished paper. Retrieved from http://userpage.fu-berlin.de/ffu/akumwelt/bc2004/download/ peters_f.pdf.

Peters, B. $\bar{G}$. (2012). Institutional theory in political science: The new institutionalism (3rd ed.). New York: Continuum Publishing Corporation.

Peters, B. G. (2015). Pursuing horizontal management: The politics of public sector coordination (1st ed.). Lawrence: University Press of Kansas.

Rocha, C., \& Lessa, I. (2009). Urban governance for food security: The alternative food system in Belo Horizonte, Brazil. International Planning Studies, 14, 389-400. https://doi.org/10.1080/ 13563471003642787.

Schmidt, V. A. (2008). Discursive institutionalism: The explanatory power of ideas and discourse. Annual Review of Political Science, 11, 303-326. https://doi.org/10.1146/annurev.polisci.11.060606.135342.

Schmidt, V. A. (2010). Taking ideas and discourse seriously: explaining change through discursive institutionalism as the fourth "new institutionalism". European Political Science Review, 2, 1-25. https:// doi.org/10.1017/S175577390999021X.

Scott, W. R. (2014). Institutions and organizations: Ideas, interests, and identities (4th ed.). Thousand Oaks: SAGE Publications.

Sharma, P., and Daugbjerg, C.. (2019). The troubled path to food sovereignty in Nepal: Ambiguities in agricultural policy reform. Agriculture and Human Values. Springer Netherlands. https://doi. org/10.1007/s10460-019-09988-1.

Shey, J. E., \& Belis, D. (2013). Building a municipal food policy regime in Minneapolis: Implications for urban climate governance. Environment and Planning. C, Government \& Policy, 31, 893910. https://doi.org/10.1068/c11235.

Sibbing, L. V., Candel, J. J. L., and Catrien, J. A. M. T. (2019). A comparative assessment of local municipal food policy integration in the Netherlands. International Planning Studies. Taylor \& Francis: 1-14. https://doi.org/10.1080/13563475.2019.1674642. 
Sonnino, R. (2009). Feeding the City: Towards a new research and planning agenda. International Planning Studies, 14, 425-435. https:// doi.org/10.1080/13563471003642795.

Sonnino, R., Tegoni, C. L. S., \& De Cunto, A. (2019). The challenge of systemic food change: Insights from cities. Cities, 85, 110-119. https://doi.org/10.1016/J.CITIES.2018.08.008.

Termeer, C. J. A. M., Drimie, S., Ingram, J., Pereira, L., \& Whittingham, M. J. (2018). A diagnostic framework for food system governance arrangements: The case of South Africa. NJAS - Wageningen Journal of Life Sciences, 84. Elsevier, 85-93. https://doi.org/10. 1016/j.njas.2017.08.001.

Yanow, D. (2007). Interpretation in policy analysis: On methods and practice. Critical Policy Studies, 1, 110-122. https://doi.org/10. 1080/19460171.2007.9518511.

Yanow, D. (2009). Dear author, dear reader: The third hermeneutic in writing and reviewing ethnography. In E. Schatz (Ed.), Political ethnography: What immersion contributes to the study of power (pp. 275-302). Chicago: The University of Chicago Press.

Yeatman, H. R. (2003). Food and nutrition policy at the local level: Key factors that influence the policy development process. Critical Public Health, 13. Taylor \& Francis Group, 125-138. https://doi. org/10.1080/0958159031000097625.

Zweynert, A. (2017). No set menu to feed cities' growing appetite. Thomson Reuters Foundation. https://www.reuters.com/article/us-global-citiesfarmingfood-idUSKCN18B136. Accessed 30 Nov 2020.

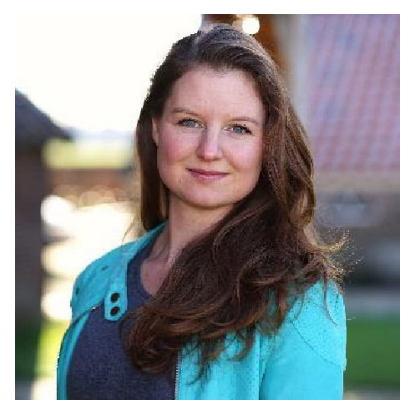

Lara V. Sibbing holds an MSc in Organic Agriculture and is currently a PhD candidate in Public Administration and Policy at Wageningen University. She studies the emergence of local food governance in the Netherlands and combines this with her duties as a food policy maker for a local government.

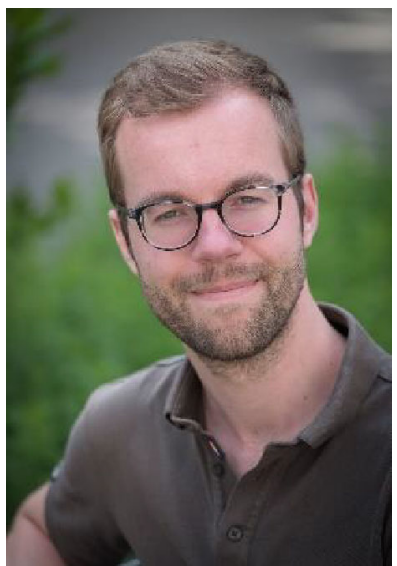

Dr. Jeroen J. L. Candel is Assistant Professor at the Public Administration and Policy group, Wageningen University \& Research, the Netherlands. His research interests include food and agricultural policy, policy integration, wicked problems, and EU politics. He authored various papers on food security governance, which have been published in both public policy and food (policy) journals. His most recent research focuses on governments' attempts to move towards better integrated food policy. 